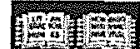

1.

9) $17 / 9$

THE DETERMINANTS OF FOREIGN DIRECT INVESTMENT IN AUSTRALIA
\end{abstract}

by

Jeannie Yih Yun Yang

Nicolaas Groenewold

MoonJoong Tcha

DISCUSSION PAPER 97.23

DEPARTMENT OF ECONOMICS

THE UNIVERSITY OF WESTERN AUSTRALIA

NEDLANDS, WESTERN AUSTRALIA 6907

ISSN 0811-6067

ISBN 0-86422-814-7 


\title{
THE DETERMINANTS OF FOREIGN DIRECT INVESTMENT IN AUSTRALIA
}

\author{
by \\ Jeannie Yih Yun Yang \\ Nicolaas Groenewold \\ MoonJoong Tcha \\ Department of Economics \\ The University of Western Australia
}

DISCUSSION PAPER 97.23

Version 3: October, 1997

ISSN 0811-6067

ISBN 0-86422-814-7 


\section{INTRODUCTION}

Foreign direct investment (FDI) has played an important part in Australia's economic development and has been growing rapidly over the past two decades. The marked expansion of FDI in Australia has been part of an international phenomenon. It has been estimated that the growth rate of world FDI flows has exceeded that of world GDP growth by almost ten percentage points over the period 1960-1990, resulting in a significant rise in the FDI/GDP ratio on a world-wide basis. ${ }^{1}$ FDI flows have continued to expand even when world trade was slow to grow, providing support for the argument that when trade-growth is retarded by trade barriers, FDI may increase as multinational firms attempt to circumvent the barriers, an effect often intended by the governments erecting the barriers. ${ }^{2}$

Australia is a recipient of large FDI flows by world standards. In 1990 it ranked seventh behind the US, the UK, Spain, France, Belgium and the Netherlands as a destination for FDI. Inflows of FDI into Australia have traditionally come from the UK, the US and Japan, with a gradual shift from the first to the last of these countries over the past 40 years. Australia has long been seen as a young country with vast natural resources which have been developed with the aid of foreign capital (provided largely by FDI) more quickly than would otherwise have been the case. This is reflected in the large foreign investment in our resource industries. Foreign ownership in the 1980 was approximately $45 \%$ in Mining and Mineral Processing (although it was also a significant $32 \%$ in Manufacturing). ${ }^{3}$

Despite the importance of FDI in the Australian economy and the marked volatility in quarter-to-quarter and year-to-year flows, there is little empirical work on the determinants of FDI inflows into Australia. The research reported in this paper seeks to make a contribution to the filling of this gap by carrying out an econometric analysis of the determinants of FDI inflows into Australia since the mid-1980s. We begin by reviewing theories of FDI and examining overseas empirical work before specifying a model which we then estimate using quarterly time-series data for Australia. We find that interest rates, wage changes, a measure of the openness of the economy and a

\footnotetext{
1 See UNCTC (1988) and UNCTAD (1993).

${ }^{2}$ See Jeon (1992) and Moore (1993).

${ }^{3}$ See MacDonald (1994).
} 
variable representing industrial disputes are important determinants of FDI inflow into Australia over the period. The estimated model successfully explains within-sample variability but this success is greater in the beginning of the sample than at the end.

Our results show that FDI inflow is positively related to the interest rate in Australia reflecting the fact that higher interest rates in the host country make foreign investment more attractive. A second significant factor was found to be the degree of openness of the economy - FDI flow is negatively related to openness suggesting that FDI is a way of circumventing trade barriers. A third factor was found to be inflation - a high inflation rate was found to discourage FDI inflow. A government wishing to stimulate FDI inflow, therefore, should maintain high (nominal) interest rates, low inflation (and thus high real rates of return) and may consider imposing trade barriers to reduce the openness of the economy.

Two variables were found to have unexpected effects - both domestic wage growth and the severity of industrial disputes were found to encourage FDI inflow. These apparently counter-intuitive results can be explained, however, in terms of an argument by Lucas (1993) who pointed out that, while higher employment costs make production in the host country less attractive than elsewhere, they may also result in a substitution of capital for labour, thus increasing FDI inflow.

\section{DETERMINANTS OF FDI INLFLOW}

There are many theories explaining FDI. It is convenient to divide the principal theories into two categories. The first explains FDI in a portfolio-allocation framework and predicts that FDI depends largely on international differences in interest rates, profit rates or other measures of return to capital. ${ }^{4}$ An important weakness of this approach is that it may explain international portfolio diversification but not FDI per se, i.e. why wealth-holders carry out FDI rather than simply purchasing foreign equity or debt instruments.

The second category resolves this difficulty by positting market imperfections of various kinds. Kindleberger (1969) notes that "for foreign direct investment to thrive, there must be some imperfections in the markets for goods or factors... or some other

\footnotetext{
${ }^{4}$ See Hymer (1976), Aggarwal (1977), Hennart (1982) for a discussion of such theories.
} 
interference in competition by government or by firms which separates markets". For FDI to be profitable there must be conditions in the host country which make production there attractive (despite the foreign firm's natural handicaps) compared, for example, to exporting to that country.

One factor which has often been part of such an explanation is that of wage differentials between the source and host countries (combined with the international immobility of labour). Empirical results have not, however, been unambiguous. The natural expectation is that a rise in the host country's wages (given wage rates in the source country) would discourage FDI flows. While this has been found by some researchers such as Goldberg (1972), Saunders (1983), Flamm and Stein (1984), Schneider and Frey (1985), Culem (1988) and Moore (1993), others have found no significant effect or even a perverse effect; examples are Caves (1974), Nankani (1979), Swedenbourg (1979), Kravis and Lipsey (1982) and Wheeler and Mody (1990).

A possible explanation of this ambiguity has been offered by Lucas (1993). Within the framework of a maximising model of an individual firm he shows that a rise in the wage rate of the host country increases costs of production and hence discourages production and also the use of capital so that FDI will fall. However, the wage rise changes the factor price-ratio and encourages the substitution of capital for labour which, ceteris paribus, increases the demand for capital and hence FDI.

An alternative explanation involves productivity movements. In a perfectly competitive market wages will reflect productivity movements but in a host country with significant market imperfections it is possible that productivity gains are not fully shred with labour so that wage rises fall behind productivity increases. In such a situation wage growth may mask a fall in labour costs (i.e. wages adjusted for productivity changes) so that the two variables move in opposite directions. Given the significant measurement difficulties, productivity-adjusted wages have not been used in the literature.

A second factor which is closely related to the wage differential and which also affects overall labour costs is that of labour disputes. Clearly, a given wage differential will make a given host country less attractive the higher is the incidence or severity of industrial disputes. Both Moore (1993) and Tcha (1994) experiment with such a variable. Tcha finds some support for its importance in his work on FDI outflows from Korea 
while Moore reports the unexpected finding that FDI is higher the higher is the average number of workers involved in a strike (a measure of the severity of industrial disputes) using German data. Given that the incidence of industrial disputes influences effective labour costs, the factor-price explanation advanced by Lucas (1993) and the productivity argument advanced above are also possible explanations of this unexpected effect of industrial disputes.

A third source of market imperfections is distortions in the foreign exchange market. Aliber $(1970,1971)$ proposes a currency preference theory based on a distinction between hard and soft currencies. He argues that a multinational firm in a hard currency area is able to borrow at lower rates in a soft currency country than local firms are, based on reputation effects. We would expect, therefore, that FDI flows from hard to soft currency areas. A broader and closely related consideration is the general state of the openness of the host country's economy. If the host country is relatively closed on the current account, incentives are created for FDI as a means of circumventing the barriers to trade. On the other hand, a relatively closed capital account (such as tight restrictions on foreign ownership) may make FDI difficult and discourage foreign investment. Much empirical work has been carried out in this general area of FDI and openness. In an UNCTAD study, Hufbauer, Lakdawalla and Malani (1994) concentrate on the relationship between trade and FDI. They use the ratio of trade to GDP as a measure of the degree of openness and also experiment with the tariff rate as an alternative. Moore (1993) used the trade-weighted ad valorem tariff rate to measure the strength of protectionist barriers but found little evidence of its significance. In a subsequent study, Wang and Swain (1995) also used the tariff rate as a measure of the openness of the host country. They too found that the effect was insignificant although the estimated coefficient had the expected positive sign. The reliability of their results is, however, subject to some question given the small number of observations they work with. BajoRubio and Sosvilla-Rivero (1994) also used a tariff rate and found it both significant and of the expected sign.

A variable that plays a similar role to the openness measures and is related to the notion of currency preference is the exchange rate. Here the explanation is that FDI is often a long-term alternative to exporting from the source country to the host country 
and that not only are tariffs and other barriers to trade important in the decision but the strength of the host country" currency as measured by its exchange rate is also an important factor. Bajo-Rubio and Sosvilla-Rivero (1994) and Wang and Swain (1995) both experimented with an exchange rate variable although without a great deal of success.

A further argument often used in empirical work is that of economies of scale and market size. It is argued that, in the face of economies of scale, FDI is more likely the greater is the host market although Agarwal (1980) has pointed out that this argument applies only in the case of production targetted at the domestic market and does not capture FDI designed to stimulate exports from the host country. The great majority of empirical studies of FDI include some measure of the size of the host market, often a measure of real GDP. Bajo-Rubia and Sosvilla-Rivero (1994), Moore (1993) and Wang and Swain (1995) all use real GDP and found it to be a significant determinant of FDI flows. Alternative measures are the rate of growth of real GDP (which Wang and Swain find significant) and GDP per capita (Schneider and Frey, 1985). The growth rate of GDP may be seen as a measure of the future potential of the host country's domestic market and the level of per capita GDP may be used to reflect the level of the host country's economic development.

Finally, political factors in the host country are often of crucial importance. Some variables already mentioned will have an important political dimension, such as the level of tariffs and the severity of non-tariff barriers to trade. Inflation rates have been used to capture the stability of macroeconomic policy by Schneider and Frey (1985) and BajoRubia and Sosvilla-Rivera (1994). Both found that inflation and FDI flows are negatively related. Other papers such as Wang and Swain (1995) use dummy variables to capture specific political events which might have an important impact on FDI flows.

We conclude from our discussion of theories and empirical work on the determinants of FDI by listing variables on the basis of the literature reviewed: a rate of return variable, the wage rate, measures of openness such as the ratio of trade to GDP and the level of tariffs, the host country's exchange rate, a measure of labour disputes and the level of GDP. We turn now to the data used in our study of FDI inflow in Australia. 


\section{DATA}

The sample period and the data frequency are largely dictated by the data available for FDI. We use quarterly non-official direct investment inflows (FDI) published by the Australian Bureau of Statistics (ABS). The definition used by the ABS for this variable changed in June 1985 prior to which direct investment was judged to have occurred when the foreign enterprise had $25 \%$ or more of the equity interest in the domestic firm; after June 1985 this percentage was lowered to $10 \%$. There is therefore no comparability between data published for the period to June 1985 and that published after that date. We therefore restrict our sample to September 1985 to March 1994 which provides 35 observation, leaving the remaining available observations for June 1994 to June 1996 for evaluation of the model using out-of-sample forecasts.

Other data used and the corresponding mnemonics were as follows: the 30-day bank-accepted bill rate (BB30) as the interest rate, real GDP as the measure of the size of the economy (GDP), wage costs (WAGES) measured by Average Weekly Earnings deflated by the CPI, the Trade Weighted Index of exchange rates (TWI), the ratio of trade (exports + imports) to GDP as a measure of openness (OPEN), the percentage change in the CPI (INF) as a measure of the stability of the domestic macroeconomic environment and, finally, the number of working days lost in industrial disputes (INDUS).

Where necessary, all data were seasonally adjusted. ${ }^{5}$ Only data for working days lost due to industrial disputes were not available in seasonally adjusted form and had a significant seasonal component. This was removed by regressing the variable on a set of seasonal dummy variables and using the residuals from this regression (SINDUS) as the regressor in the FDI equation. All other data were available in either seasonally adjusted form (GDP, WAGES, exports and imports) or exhibited no discernible seasonal pattern (FDI, BB30, TWI and INF).

Before proceeding to the estimation of the FDI equation, we tested all variables for a unit root and, if a unit root was present, we proceeded to test for a unit root in the

\footnotetext{
${ }^{5}$ It has been argued recently that seasonal adjustment procedures may introduce spurious properties into the data; see e.g. Leong (1996). An alternative to the use of seasonally adjusted data is to test for seasonal unit roots and cointegration following the procedures suggested by Hyllenberg et al. (1990) and to make appropriate transformations of the data as suggested by the outcomes of these procedures. Extensive experimentation along these lines has been carried out and the results were generally statistically inferior to those reported here although not inconsistent with them.
} 
first difference. The results are in Table 1. The table reports both augmented DickeyFuller (ADF) and Phillips-Perron (PP) tests. In both cases the null hypothesis is that there is a unit root in the process. The tests for a unit root in the levels of the variables included a trend and the tests of the first differences did not. The tests were computed on Shazam which computes the number of lagged first differences in the ADF test and the length of the truncation lag in the PP test as the longest lag with a significant autocorrelation in the first-differenced form of the variable. The tests often give conflicting results for the level form of the variables. Only FDI is unambiguously stationary and GDP, TWI, BB30 and WAGES are non-stationary. For the remaining variables the results are mixed. Given the nature of the variables and the relatively short span of data, we resolve all these ambiguities in favour of stationarity. Tests for a unit root in the first difference of the non-stationary variables indicate that they are all $I(1)$ so that first-differencing is sufficient to induce stationarity. We, therefore, use the nonstationary variables in first-difference form in the FDI equation.

\section{RESULTS}

The review of the theoretical and empirical literature in Section II and the analysis of the stationarity of the variables in Section III suggests the specification of the following static equation for FDI inflows: ${ }^{6}$

$$
\begin{aligned}
& \mathrm{FDI}_{\mathrm{t}}=\beta_{0}+\beta_{1} \Delta \mathrm{BB} 0_{\mathrm{t}}+\beta_{2} \Delta \mathrm{TWI}_{\mathrm{t}}+\beta_{3} \Delta \mathrm{GDP}_{\mathrm{t}}+\beta_{4} \Delta \mathrm{WAGES}_{\mathrm{t}}+\beta_{5} \text { OPEN }_{\mathrm{t}}+\beta_{6} \text { SINDUS }_{\mathrm{t}} \\
& +\beta_{7} \mathrm{IFF}_{\mathrm{t}}
\end{aligned}
$$

We initially estimated the equation in general dynamic form with current and lagged values of all the variables including the dependent variable. Given our use of quarterly data, we would have preferred to start with four lags on all variables since FDI may be slow to respond to some of its determinants. However, the small sample precluded such a specification. The results of the general dynamic form of the equation

\footnotetext{
${ }^{6}$ Experimentation with a log-linear form of this equation was also undertaken but the results were not in general dependent on which functional form was used.
} 
using the current and once-lagged values of the variables are given as Equation 1 in Table 2. The value of $R^{2}$ is satisfactory although the large number of regressors results in a low $\overline{\mathrm{R}}^{2}$ and a relatively low $\mathrm{F}$ statistic. The latter is significant at the $10 \%$ but not at the $5 \%$ level. The Durbin-Watson (DW) statistic lies in the uncertain region and the LM statistic for first- to fourth-order autocorrelation is significant at the 5\% level. Only three of the explanatory variables are significant at the $5 \%$ level.

We next eliminated the insignificant variables but left at least either the current or lagged value of each of the regressors. The results are reported as Equation 2 in Table 2. $\mathrm{R}^{2}$ is a little lower but $\overline{\mathrm{R}}^{2}$ is greatly improved and $\mathrm{F}$ is clearly significant. The DW statistic is lower but still in the indeterminate region although the LM test statistic indicates the absence of autocorrelation. All but three of the variables are significant at the $10 \%$ level. If we drop the insignificant variables $\triangle T W I$ and $\triangle G D P$, Equation 3 results. In this equation there is a further improvement in $\bar{R}^{2}$ and $F$ and no evidence of autocorrelation. However, both INF and SINDUS are insignificant, although SINDUS is significant at $10 \%$ and INF at 15\%. If we delete SINDUS the results are as in Equation 4 where all variables including INF are significant (at the 10\% level) and if we delete INF but retain SINDUS, Equation 5 results in which, again, all variables are significant, but now at $5 \%$.

There is little to choose between equations 3,4 and 5 in terms of $\bar{R}^{2}$ and t-ratios. The signs of the coefficients are generally as predicted by the theory discussed in section II. In all cases the interest rate variable $\triangle B B 30$ has the expected sign: the higher is the domestic interest rate the higher are FDI inflows. Similarly, the inflation variable in equations 3 and 5 has the correct sign: high domestic inflation is a sign of weak domestic macroeconomic policy and thus discourages capital inflow.

The wage variables have a positive sign in all equations. This is contrary to the argument that inflow is partly a response to lower host country wage costs. However, it may simply reflect the factor-substitution effect put forward by Lucas (1993) or the fact that real wages have grown more slowly than productivity over the sample period so that productivity-adjusted real wages have actually fallen. The real wage variable may therefore have been negatively correlated with real unit labour costs over our sample period, producing a positive sign. 
The positive coefficient on the OPEN variable supports the argument made earlier that FDI inflows are a substitute for trade so that a fall in trade flows (as evidenced by a fall in OPEN) may be associated with a rise in FDI inflows. This is in contrast to the more common argument that greater openness of the economy encourages both FDI and trade flows so that these two variables would be positively correlated, ceteris paribus.

Finally, a positive coefficient of the industrial disputes variable is contrary to the prediction that industrial disputes "scare off" foreign investment. However, since it is ultimately an element of real unit labour costs, its sign may simply reflect the same factors as those underlying the positive coefficient on the wages variable discussed above. A positive effect is not without precedent; Moore (1993) found an unexpected positive relationship between the average number of workers involved in a strike and the level of FDI inflows.

We undertake further model evaluation with the aid of Figures 1 and 2. Figure 1 pictures the within-sample performance of the model. We have chosen Equation 4 as our preferred equation because it avoids the perverse sign on SINDUS. It is clear from the figure that the model explains a great deal of the fluctuations in FDI inflow over the period to 1994 although the ability of the model to track the dependent variable appears better in the first half of the sample period than it does in the second half.

Figure 2 pictures the model's predictive power beyond the end of the sample and it is clear from this figure that the model performs very poorly out-of-sample. There are two aspects of this poor performance - the first is that the forecasts are much smoother than the actual data. This is somewhat surprising in the light of the within-sample performance depicted in Figure 1 where the forecast series is not markedly smoother than the actual although there is a failure to predict the sharp fluctuations late in the sample and part of the out-of-sample performance may be a continuation of this failure. The second aspect of the poor out-of-sample performance of the model is the complete failure to capture the very large positive and negative values of FDI inflows in the December quarter of 1994 and September quarter of 1995 respectively. Given that these values are considerably outside the range of fluctuations experienced during the sample period, however, it is perhaps too much to ask of the model that they are predicted out of the sample. 


\section{CONCLUSIONS}

In this paper we have addressed the question of the determinants of foreign direct investment (FDD) inflow into Australia. After surveying both the theoretical and empirical literature, we estimated a model which explained FDI inflow in terms of a short-term interest rate, real GDP, the trade-weighted index of the exchange rate, a measure of the importance of international trade as a fraction of GDP, a measure of labour disputes, wages costs and the inflation rate.

The model was estimated with quarterly data for the period 1985-1994, the starting-point of the sample period being restricted by the availability of data prior to 1985 and the final point of the sample being determined by our desire to perform out-ofsample forecasting evaluation of the model. Only GDP and the TWI were not significant in either current or lagged form. We found that all estimated coefficient signs were plausible. This is similar to an earlier finding for Germany by Moore (1993). The estimated model performed well in terms of within-sample explanation of fluctuations in FDI inflow although less well in the second part of the sample than the first. This deterioration in explanatory performance was carried over into the out-of-sample forecasts where the model failed to predict particularly large fluctuations in the post-1994 period. 


\section{REFERENCES}

Agarwal, J. P. (1980), "Determinants of Foreign Direct Investment: A Survey", Weltwirtschaftliches Archiv, 116, 739-773.

Aggarwal, R. (1977), "Theories of Foreign Direct Investment: A Summary of Recent Research and a Proposed Unifying Paradigm", Economic Affairs, 22, 31-44.

Aliber, R. Z. (1970), "A Theory of Foreign Direct Investment", in C. P. Kindleberger (ed.), The International Corporation, Cambridge, 17-34.

Aliber, R. Z. (1971), "The Multinational Enterprise in a Multiple Currency World", in J. H. Dunning (ed.), The Multinational Enterprise, London, 49-56.

Bajo-Rubio, O. and Sosvilla-Rivero, S. (1994), "An Econometric Analysis of Foreign Direct Investment in Spain, 1964-89", Southern Economic Journal, 61, 104-120.

Caves, R. E. (1974), "Causes of Direct Investment: Foreign Firms' Shares in Canadian and United Kingdom Manufacturing Industries", Review of Economics and Statistics, 56, 279-293.

Culem, C. G. (1988), "The Locational Determinant of Direct Foreign Investment Among Industrialised Countries", European Economic Review, 32, 885-904.

Flamm, K. and Stein, J. (1989), "Exchange Rates and Foreign Direct Investment: An Imperfect Capital Markets Approach", NBER Working Paper 2914.

Goldberg, M. A. (1972), "The Determinants of US Direct Foreign Investment in the EEC: Comment", American Economic Review, 62, 692-699.

Hennart, J. F. (1982), A Theory of the Multinational Enterprise, The University of Michigan Press, Michigan.

Hufbauer, G., D. Lakdawalla and A. Malani, (1994), "Determinants of Direct Foreign Investment and its Connection to Trade", UNCTAD Review, 39-51.

Hyllenberg, S., R. F. Engle, C. W. J. Granger and B. S. Yoo (1990), "Seasonal Integration and Cointegration", Journal of Econometrics, 44, 159-178.

Hymer, S. H. (1976), The International Operations of National Firms: A Study of Direct Foreign Investment, Cambridge University Press, Cambridge.

Jeon, Y. D. (1992), "The Determinants of Korean Foreign Direct Investment in Manufacturing Industries”, Weltwirtschaftliches Archiv, 128, 527-541. 
Kindleberger, C. P. (1969), American Business: Six Lectures on Direct Investment, Yale University Press.

Kravis, I. B. and R. G. Lipsey, (1982), "The Location of Overseas Production and Production for Exports by US Multinational Firms", Journal of International Economics, 12, 201-223.

Leong, K. (1996), "Seasonal Integration in Economic Time Series" Mathematics and Computers in Simulation, forthcoming.

Lucas, R. B. (1993), "On the Determinants of Foreign Direct Investment: Evidence from east and Southeast Asia”, World Development, 21, 391-406.

MacDonald, G. (1994), "Multinational Enterprises in Australia: A Preliminary Overview of the Effects on Employment", Working Paper No. 1011, ILO, Geneva.

Moore, M. O. (1993), "Determinants of German Manufacturing Direct Investment: 1980 - 1988”, Weltwirtschaftliches Archiv, 129, 120-137.

Nankani, G. T. (1979), The Intercountry Distribution of Direct Foreign Investment, Garland, NY.

Saunders, R. (1983), "The Determinants of Interindustry Variation of Foreign Ownership in Canadian Manufacturing", Canadian Journal of Economics, 15, 77-84.

Schneider, F. and B. S. Frey (1985), "Economic and Political Determinants of Foreign Direct Investment", World Development, 13, 161-175.

Swedenbourg, B. (1979), The Multinational Operations of Swedish Firms: Analysis of Determinants and Effects, Industrial Institute of Economic and Social Research, Stockholm.

Tcha, M. (1994), "Labour Disputes and Direct Foreign Investment: The Experience of Korea”, Discussion Paper 94-14, University of Western Australia, Department of Economics.

United Nations Conference on Trade and Development (UNCTAD) (1993), World Investment Report 1993: Transnational Corporations and Integrated International Production, United Nations, NY.

United Nations Conference on Transnational Corporations (UNCTC) (1988), Transnational Corporations in World Development: Trends and Prospects, United Nations, NY. 
Wang, Z. Q. and N. J. Swain (1995), "The Determinants of Foreign Direct Investment in Transforming Economies: Empirical Evidence from Hungary and China", Weltwirtschaftliches Archiv, 131, 359-382.

Wheeler, D. and A. Mody (1990), "Risk and Rewards in International Location Tournaments: The case of US Firms", The World Bank, Washington, DC. 
TABLE 1: TESTS FOR A UNIT ROOT

\begin{tabular}{|c|c|c|c|}
\hline Variable & ADF & PP & $10 \%$ Critical Value \\
\hline GDP & -1.4529 & -0.9321 & -3.13 \\
\hline$\triangle \mathrm{GDP}$ & -2.4055 & -5.1889 & -2.57 \\
\hline FDI & -4.0907 & -5.1047 & -3.13 \\
\hline OPEN & -2.9061 & -4.1712 & -3.13 \\
\hline$\triangle \mathrm{OPEN}$ & -3.9597 & -8.4550 & -2.57 \\
\hline TWI & -1.7548 & -1.8609 & -3.13 \\
\hline$\Delta \mathrm{TWI}$ & $-5.3530^{\circ}$ & -5.4047 & -2.57 \\
\hline SINDUS & -2.4645 & -5.8098 & -3.13 \\
\hline$\triangle$ SINDUS & -4.0872 & -10.1210 & -2.57 \\
\hline BB30 & -2.4672 & -1.4230 & -3.13 \\
\hline$\triangle \mathrm{BB30}$ & -1.6431 & -3.0741 & -2.57 \\
\hline WAGES & -2.4690 & -2.4741 & -3.13 \\
\hline$\triangle$ WAGES & -2.0452 & -6.5006 & -2.57 \\
\hline INF & -3.1012 & -4.8388 & -3.13 \\
\hline$\triangle \mathrm{INE}$ & -3.9981 & -9.8057 & -2.57 \\
\hline
\end{tabular}

Note: ADF denotes the Augmented Dickey-Fuller test and PP denotes the PhillipsPeron test. 
TABLE 2: FOREIGN DIRECT INVESTMENT INTO AUSTRALIA

(September 1985 - March 1994)

\begin{tabular}{|c|c|c|c|c|c|}
\hline VARIABLE & EQUATION 1 & EQUATION 2 & EQUATION 3 & EQUATION 4 & EQUATION 5 \\
\hline FDI $(-1)$ & $\begin{array}{l}0.1126 \\
(0.57)\end{array}$ & & & & \\
\hline$\triangle \mathrm{BB30}$ & $\begin{array}{c}-0.5528 \\
(-0.37)\end{array}$ & & & & \\
\hline$\triangle B B 30(-1)$ & $\begin{array}{c}5.8758^{\cdots} \\
(3.19)\end{array}$ & $\begin{array}{c}5.7923^{* \cdots} \\
(4.60)\end{array}$ & $\begin{array}{c}5.8353^{\cdots} \cdots \\
(5.06)\end{array}$ & $\begin{array}{c}5.9491 \cdots \\
(4.95)\end{array}$ & $\begin{array}{c}5.2192^{\cdots *} \\
(4.66)\end{array}$ \\
\hline$\Delta \mathrm{TWI}$ & $\begin{array}{c}0.9480^{\circ} \\
(1.39)^{\circ}\end{array}$ & $\begin{array}{l}0.5857 \\
(1.16)\end{array}$ & & & \\
\hline$\Delta \mathrm{TWI}(-1)$ & $\begin{array}{l}0.1136 \\
(0.19)\end{array}$ & & & & \\
\hline$\triangle \mathrm{GDP}$ & $\begin{array}{l}-1.5651 \\
(-0.83)\end{array}$ & $\begin{array}{c}-0.8988 \\
(-0.59)\end{array}$ & & & \\
\hline$\triangle G D P(-1)$ & $\begin{array}{c}-0.3546 \\
(-0.19)\end{array}$ & & & & \\
\hline$\triangle W A G E S$ & $\begin{array}{c}1.2299^{\cdots} \\
(2.48)\end{array}$ & $\begin{array}{c}1.129 \mathrm{I}^{\cdots} \\
(3.04)\end{array}$ & $\begin{array}{c}1.1261^{\cdots} \\
(3.06)\end{array}$ & $\begin{array}{c}0.9768 \cdots \\
(2.61)\end{array}$ & $\begin{array}{c}1.0638^{\cdots \cdots} \\
(2.82)\end{array}$ \\
\hline$\triangle$ WAGES $(-1)$ & $\begin{array}{c}0.8666^{\circ} \\
(1.89)\end{array}$ & $\begin{array}{c}0.7970^{\circ} \\
(2.10)\end{array}$ & $\begin{array}{c}0.7415^{*} \\
(2.05)\end{array}$ & $\begin{array}{c}0.7927^{* *} \\
(2.10)\end{array}$ & $\begin{array}{c}0.8141^{*} \\
(2.20)\end{array}$ \\
\hline OPEN & $\begin{array}{c}-0.4155^{\circ} \\
(-1.69)\end{array}$ & $\begin{array}{c}-0.2261^{\cdots} \\
(-3.18)\end{array}$ & $\begin{array}{c}-0.1958^{\cdots \cdots} \\
(-2.94)\end{array}$ & $\begin{array}{c}-0.2343^{\cdots *} \\
(-3.54)\end{array}$ & $\begin{array}{c}-0.1133 \cdots \\
(-2.59)\end{array}$ \\
\hline OPEN $(-1)$ & $\begin{array}{c}0.2043 \\
(1.04)\end{array}$ & & & & \\
\hline SINDUS & $\begin{array}{l}0.7654 \\
(0.66)\end{array}$ & $\begin{array}{l}1.1067 \\
(1.18)\end{array}$ & $\begin{array}{c}1.5660^{\circ} \\
(1.84)\end{array}$ & & $\begin{array}{c}1.8638^{* *} \\
(2.17)\end{array}$ \\
\hline SINDUS $(-1)$ & $\begin{array}{c}-0.3038 \\
(-0.25)\end{array}$ & & & & \\
\hline INF & $\begin{array}{l}2.0385 \\
(0.60)\end{array}$ & & & & \\
\hline $\operatorname{INF}(-1)$ & $\begin{array}{c}-6.0284^{* *} \\
(-1.68)\end{array}$ & $\begin{array}{c}-4.9391^{* *} \\
(-1.93)\end{array}$ & $\begin{array}{l}-3.787^{\circ} \\
(-1.60)\end{array}$ & $\begin{array}{c}-4.7325^{\circ} \\
(-1.96)\end{array}$ & \\
\hline CONSTANT & $\begin{array}{c}100.1500 \\
(2.42)\end{array}$ & $\begin{array}{c}106.7900 \\
(3.78)\end{array}$ & $\begin{array}{c}93.8010 \\
(3.59)\end{array}$ & $\begin{array}{c}109.1300 \\
(4.22)\end{array}$ & $\begin{array}{c}59.6940 \\
(3.82)\end{array}$ \\
\hline
\end{tabular}


To be continued

Continued

TABLE 2 : FOREIGN DIRECT INVESTMENT
INTO AUSTRALIA

(September 1985 - March 1994)

\begin{tabular}{|l||c|c|c|c|c|}
\hline VARIABLE & EQUATION 1 & EQUATION 2 & EQUATION 3 & EQUATION 4 & EQUATION 5 \\
\hline \hline $\mathbf{R}^{2}$ & 0.6740 & 0.6236 & 0.5961 & 0.5417 & 0.5547 \\
$\overline{\mathbf{R}}^{2}$ & 0.3684 & 0.4927 & 0.4992 & 0.4536 & 0.4690 \\
$\mathbf{F}$ & 2.2052 & 4.7632 & 6.1502 & 6.1461 & 6.4764 \\
$\mathbf{D W}$ & 2.5794 & 2.3153 & 2.3249 & 2.3140 & 2.4337 \\
$\mathbf{L M}$ & 10.4475 & 2.9507 & 2.8059 & 5.3153 & 3.8158 \\
\hline
\end{tabular}

Notes: Numbers in parentheses are t-statistics.

$*, * *$ and $* * *$ denote that coefficients are significant at $10 \%, 5 \%$ and $1 \%$ levels respectively. DW is the Durbin Watson statistic and LM is the Lagrange Multiplier statistic. 


\section{FIGURE 1: WITHIN SAMPLE FORECASTS}

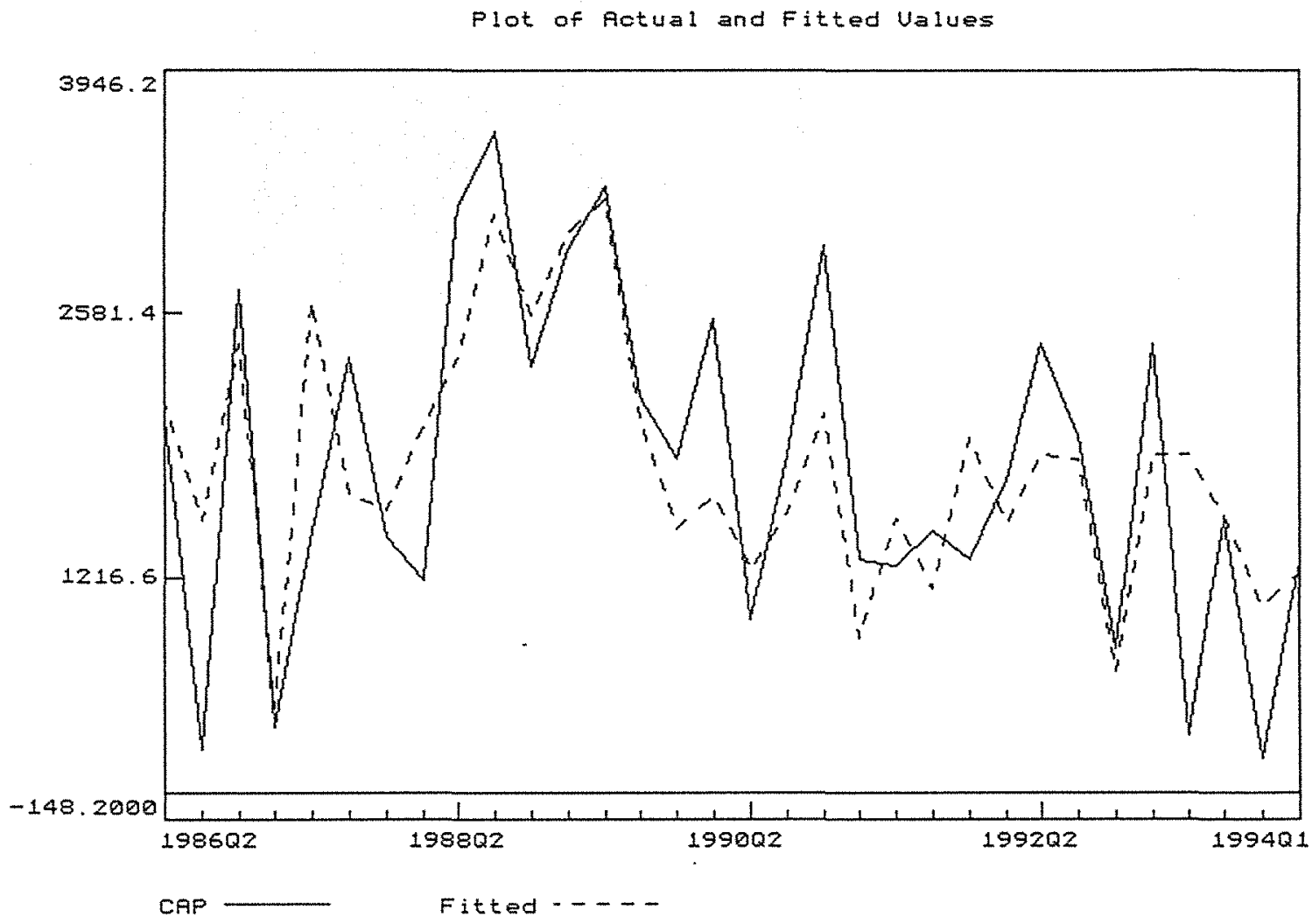

Note: "CAP" denotes the actual inflow of FDI into Australia and "Fitted" denotes the fitted value of FDI into Australia obtained from Equation 4. 


\section{FIGURE 2: OUT-OF-SAMPLE FORECASTS}

Plot of Rotual and Single Equation Statio Forecast $(s)$

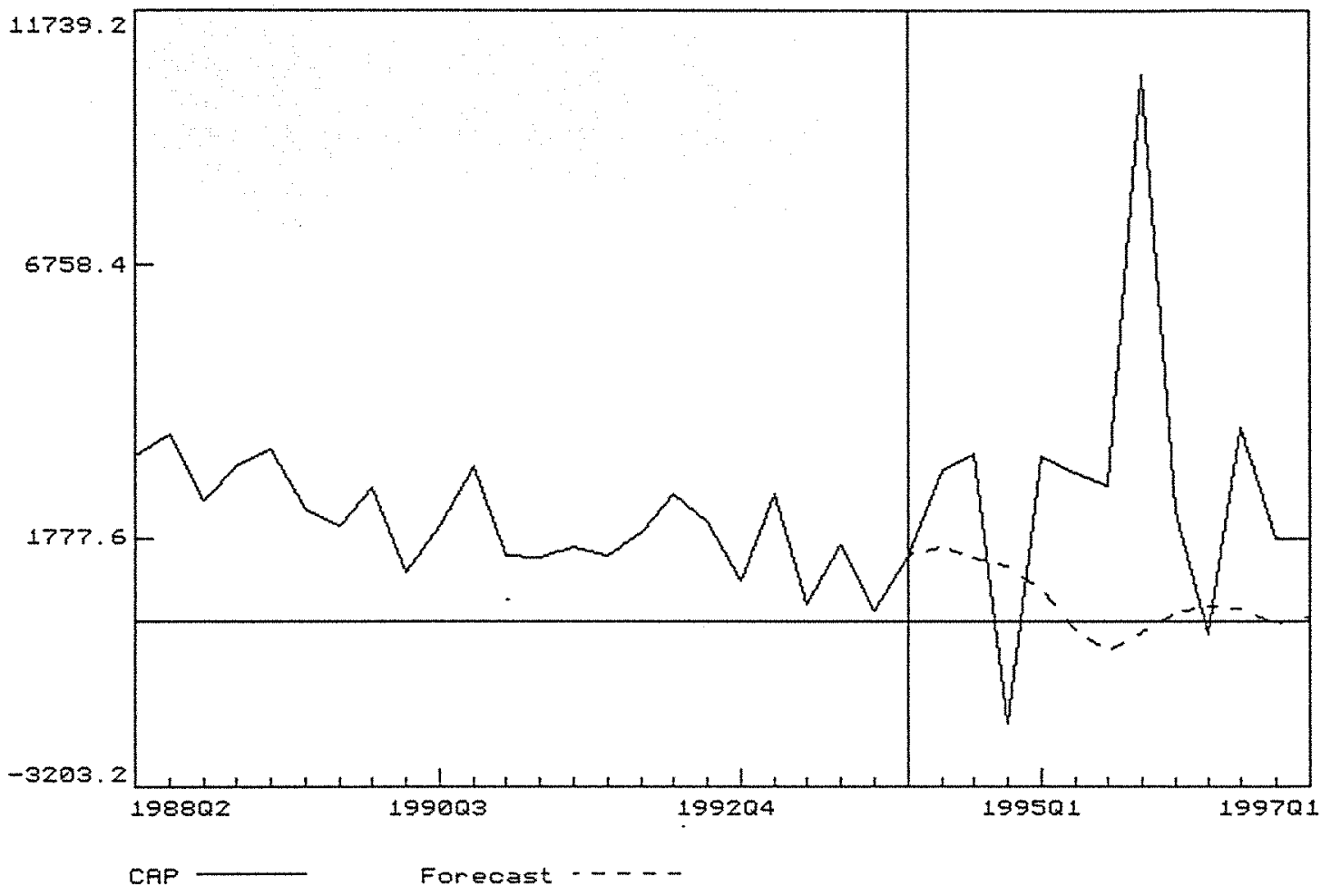

Note: "CAP" denotes the actual inflow of FDI into Australia and "Forecast" denotes the value of FDI inflow into Australia estimated by Equation 4. 